\section{INTESTINAL OBSTRUCTION AFTER GASTRO-ENTEROSTOMY.}

- To the Editors of THE LANCET.

Sirs,--In THE Lancex of August 20th, p. 526, Mr. H. M. W. Gray records a case of intestinal obstruction after gastro-enterostomy. The obstruction was caused by the small intestine having insinuated itself through the ring formed by the under layer of the transverse colon above and the jejunal loop with its mesentery below. In his comment Mr. Gray remarks that he can find no record in the literature on gastro-enterostomy of such a condition. May I point out that a similar case is recorded by Dr. W. J. Mayo of Rochester, Minnesota, in the Annals of Surgery for August, 1902 ? The details of this case are reported in the second edition of "Diseases of the Stomach" (p. 257) by Mr. Mayo Robson and myself.-I am, Sirs, yours faithfully,

Leeds, August 30th, 1904.

B. G. A. Moxnihan.

\section{THE SERUM TREATMENT OF EXOPH.} THALMIC GOITRE.

\section{To the Editors of THE LANCET.}

- SiRs, - I have read with much interest Dr. G. R. Murray's note on this subject in THE LANCET of August 27th, p. 583, as for some months past $I$ have been trying to produce a satisfactory thyreolytic serum. One objection to Dr. Murray's method occurs to me. T'hese antibodies are usually quite specific. Thus a sheep injected with ox's blood develops an antibody for the blood of an ox and not for that of any other animal. Portis injected emulsions of dog's thyroids into goats and produced a serum which was cytolytic for dogs. Probably, therefore, it will be necessary to employ emulsions of human thyroids for injection into the selected animal to produce a satisfactory serum for Graves's disease. I am, Sirs, yours faithfully,

IV. LANGDON BROWN.

III Finsbury-square, E.C., August 29th, 1904.

\section{THE UTILITY OR OTHERWISE OF FEVER HOSPITALS: THE NEED FOR AN INQUIRY.}

\section{To the Editors of THE LANCET.}

SIRs, - It is now becoming generally recognised that the results which are being achieved by fever hospitals-erected and maintained entirely out of public funds-are not nearly so great as we were wont to believe. It is not surprising. therefore, that a strong feeling is growing up that the subject calls for full investigation by some specially appointed tribunal.

In the leading article on this subject in your issue of August 27th you, Sirs, say: "The issues raised are complex, but we think that a case is made out for inquiry, and hope that that inquiry, if instituted, will be conducted without any introduction of personalities." The British Medical Journal, in an editorial on Feb. 27th, wrote as follows: "The facts and arguments advanced ...... are sufficiently cogent to afford justification for the suggestion that the advantages and dis. advantages of hospitals in which cases of infectious disease are aggregated would be a suitable subject for investigation for a Select Committee, if not by a Royal Commission." Another weekly medical journal, the Medical Press, Dec. 30th, 1903, wrote: "Three questions suggest themselves. Are isolation hospitals effecting the purpose for which they were introduced? Are the drawbacks to the system inherent or capable of being removed? Are the enormous sums which these hospitals cost justified or could the money be better applied? These are grave matters and fully warrant the demand for combined inquiry by some representative body in the profession." 'The Medical Magazine, March, 1904, wrote in reference to fever hospitals : "It is a question of national gravity as to their continuance on the present system and in any case an official inquiry seems to be demanded. we can only repeat our conviction that a searching inquiry appears to be necessary."

A resolution calling for an inquiry was passed in October, 1903, by the Southern Branch of the Society of Medical Officers of Health and more recently by the Congress of the
Royal Institute of Public Health hold at Folkestone last July. The demand for an incyuiry being, therefore, clearly established it remains to be consiclered what form the inquiry should take. The subject is armittedly a highly complex one, and it is one of national importance for it concerns almost every sanitary district throughout the country. Moreover, the annual charge on the rates entailed by fever hospitals is, when compared with other items of preventive medicine expenditure, very heavy indeed. The plea which is now being put forward that these institutions are a great convenience to the public is not sufficient alone to justify this expenditure.

It is not unreasonable to claim that the subject is of sufficient importance to justify the appointment of a really authoritative tribunal, preferably a Royal Commission. The second point on which $I$ wish strong]y to insist is that the tribunal, whatever else its qualifications, must be an impartial one. 'This is all important. T'his question of the utility of fever hospitals has, as is well known, become a keenly controversial one. It is unfortunate that it should be so, but the fact remains. Those who have taken an active part in this controversy, on either sicle, are disqualified to sit in judgment, however well qualified they may otherwise be. So also those sanitarians who have been actively instrumental in securing the provision of fever hospitals in the past cannot be regarded as impartial or unprejudiced observers, though I am well aware that this will exclude many of our older and most able officers of health. 'There are, however, plenty of men available well qualified both as regards training and experience to investigate such a subject as this and without being handicapped by long-standing convictions or preconceptions. There is no necessity that the commission should be composed entirely of medical men; indeed, it would be better that it should contain some laymen. It should be the duty of this commission to receive witnesses and to collect evidence from every source and I venture to predict that when all available evidence has been obtained it will not be impossible for impartial judges to arrive at some definite conclusion.

Leicester, Sept. 7th, 1904. I am, Sirs, yours faithfully,

C. Killick Millard.

\section{THE INDIAN MEDICAL SERVICE. To the Editors of THE LANCET.}

SiRs,-In The LANCET of July 23rd, 1904, p. 254, "Lieutenant-Colonel, I.M.S.," writes with reference to an order which is called "the latest order of Lord Curzon's Government, dealing with the relations between officers of the Indian Medical Service and certain of their native patients." He further states with reference to this order that it "will make such medical officer liable to have his name removed from the Medical Register for conduct infamous in a professional respect" for the reasons given -viz., for betraying confidence to a third person-a civil political officer, \&c. In THE LANCET of Sept. 3rd, p. 724, in dealing with the present position of the Indian Medical Service and comparing it with the Royal Army Medical Corps you say: "The blots on the present regulations for the Indian Medical Service are as follows," and under paragraph 3 you state: "The order of the present Government of India that an officer of the Indian Medical Service must refer the question of the amount of his fees when above a certain low limit to the civil authority. The recent orders might necessitate the violation of professional secrecy." The order mentioned is, as will be observed from the under-mentioned printed order No. 437 Home Department (Medical), dated Simla, July 26th, 1893 a modification of the same and in supersession of the notifica tion of the order No. 813 of the Home Department, dated Dec. 8 th, $1888:-$

No. 437.

Home Department, Medical, Simla, July 26th, 1893.

In supersession of the notification of this Department No. 813, dated the 8th December, 1888, the Governor-General in Council is pleased to make the following rules regarding the remuneration of medical officer for attendance on native chiefs and nobles and native gentlemen of high position in a Native State.

2. When a native chief or noble or gentleman of high position desires the professional attendance of any medical officer of Government the latter will be at liberty to attend him, provided that such attendance does not interfere with the due performance of his ordinary duties. The special permission of the local government will, however, be necessary when such attendance involves the absence of the officer from those duties for any substantial time.

3. The native chief, noble, or gentleman may offer any medical office 